\title{
USHUL NAHWI SEJARAH DAN PERKEMBANGANNYA
}

\author{
Ahmad Zaky \\ Dosen Program Studi Pendidikan Bahasa Arab STAI As-Sunnah Deli Serdang \\ Jl. Medan-Tg. Morawa, km. 13, Gg. Darmo, Bangun Sari, Tg. Morawa, Deli \\ Serdang, SUMUT \\ zakybenkhudri@gmail.com
}

\begin{abstract}
Abstrak: Ushul an-nahwi adalah ilmu yang membahas atau mengkaji tentang aladillah an-nahwiyah (sumber hukum dalam nahwu), tata cara mengeluarkan kaidah-kaidah nahwu, serta pengaplikasiannya. Adapun yang dimaksud dengan al-adillah an-nahwiyah adalah sama', qiyâs, ijmâ',dan istishâb. Konsep Ushul nahwi pertama kali muncul abad ke-4 $H$ dikemukakan oleh Ibn as-Sarraj, kemudian dipopulerkan oleh Ibn Jinni, kemudian pada abad ke-6 H kembali diikuti oleh al-Anbari dan as-Suyuti. Istilah Ushul an-nahwi dalam banyak hal muncul di kalangan ulama nahwu terinspirasi oleh wacana keilmuan yang dikembangkan oleh ulama figh atau Ushul fiqh. Ilmu Ushul fiqh merupakan ilmu yang paling banyak memberikkan pengaruh terhadap kajian Ushul an-nahwi, hal ini dapat terlihat dari banyaknya istilah-istilah yang digunakan dalam ilmu Ushul an-nahwi yang diambil dari istilah-istlilah ushul fiqh.
\end{abstract}

Kata Kunci : Ushul Nahwi, Sejarah, Perkembangan

\section{Pendahuluan}

Berbagai kasus lahn dan perbedaan qirâ'at menjadi faktor utama yang mendorong ide dan gagasan untuk membakukan kaidah-kaidah bahasa atau gramatika (nahwu) bahasa Arab. Perumusan kaidah-kaidah yang telah dilakukan oleh para ulama semenjak abad pertama hijriah sampai melewati beberapa fase pada dasarnya secara kualitas dan esensi materi telah berbicara tentang substansi Ushul an-nahwi. Sebab para ulama nahwu dalam merumuskan kaidah-kaidah nahwu mesti mendasarkan pada al-adillah an-nahwiyah yaitu sama',qiyâs, ijmâ' dan istishâb.

Sebagaimana ushul fiqh, Ushul an-nahwimerupakan prinsip-prinsip yang melandasi ilmu nahwu dalam berbagai persoalan dan aplikasinya. Ushul an-nahwi tidak hanya menyoroti sumber-sumber, dalil-dalil dan prinsip-prinsip perumusan nahwu sebagai ilmu, melainkan juga mengkaji berbagai perbedaan pendapat dikalangan ahli nahwu dalam memahami fenomena-fenomena bahasa Arab sejak masa jahiliyah sampai masa pembakuan dan pembukuan nahwu. 
Sebagaimana dalam kajian ushul fiqh, istilah ushul juga digunakan oleh para ahli bahasa dalam ilmu nahwu. Sebagaimana peran penting ushul fiqh dalam kajian fiqh, maka Ushul an-nahwi juga mempunyai peran yang sangat siqnifikan dalam ilmu nahwu.

Tulisanini akan membahas tentang apakah itu ilmu Ushul an-nahwi? Bagaimana perkembangannya? Dan apa pengaruh ilmu Ushulfiqh terhadap ilmu Ushul an-nahwi?

\section{Pembahasan}

\section{PengertianUshulan-Nahwi}

Secara bahasa kata-kataUshul an-nahwi berasal dari dua kata, yaituUshul dan an-nahwi. Secara bahasa, kataUshul merupakan bentuk jama' dari kata ashlu yang berarti " أَسفلُ كُلِّ شَيْءِ yaitu bagian paling bawah darisegala sesuatu. ${ }^{1}$ Sedangkan secara istilah, kataUshul dimaknai dengan sesuatu yang kuat, yang menjadi dalil, dan kaedah suatu hal. ${ }^{2}$

Kata an-Nahwu secara bahasa bermakna "القَصدُ والطَّرِيقُُ"

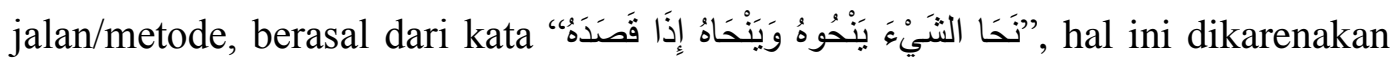
maksud dari nahwu adalah mengetahui kebenaran. ${ }^{3}$

Sedangkan secara istilah, kata nahwu memiliki banyak pengertian, salah


yang membahas tentang keadaan akhir kalimat, baik secara $i$ 'râb maupun secara binấ, ${ }^{4}$

Adapun makna Ushul an-nahwi secara istilah, ada beberapa pengertianyang dikemukakan oleh para ahli, di antaranya:

Menurut Ibnu Anbari pengertianUshul an-nahwi adalah:

$$
\text { معنى أصول النحو: أدلة النحو التي تفرعت منها فروعه وفصوله }
$$

\footnotetext{
${ }^{1}$ Muhammad bin Mukrim Ibnu Manzhur, Lisân al- 'Arabi, (Beirut: Dâr al-Shadir, 1414), juz 11, hal. 16

2 'Arraq Jabr Syallal, al-'Alâqah baina 'ilmi Ushul al-Fiqh wa 'ilmi Ushul an-Nahwi, (Tarmiyah: Al-Jâmi’ah al-'Irâqy, tth.), hal. 291

${ }^{3}$ Ibid., hal. 293

${ }^{4}$ Muhammad bin Ali as-Shaban, Hâsyiyah as-Shaban 'ala al-Asyumi, (Beirut: Dâr alKutub al-'Ilmiyah, 1997), juz 1, hal. 24
} 
Ushulan-nahwi adalah al-adillah an-nahwiyah yang dengannya munculah cabang-cabangnya dan sub-sub kajiannya. ${ }^{5}$

As-Suyuti mengemukakan rumusan pengertian Ushul an-nahwi dalam kitabnya al-Iqtirâh:

$$
\text { أصول النحو علم يبحث فيه عن أدلة النحو الإجمالية من حيث هي أدلته وكيفية الإستدلال بهاوحال }
$$

Ushulan-nahwi adalah ilmu yang mengkaji tentang Adillah an-Nahwi (sumber hukum dalam nahwu), tata cara mengeluarkan kaidah-kaidah nahwu dengan menggunakan adillah nahwi, serta pengaplikasiannya. ${ }^{6}$

Adapun pengertian Ushul an-nahwi sebagaimana yang dipaparkan oleh Khalid Sa'ad Muhammad Sya'ban: "Pada awalnya istilah Ushul an-nahwi di kalangan ahli nahwu dipahami sebagai kaidah-kaidah dasar yang terdapat dalam nahwu (al-qawâ'id al-asâsiyah fi an-nahwi), atau dipahami juga sebagai dasardasar metodologi dan juga dalil-dalil umum yang dengan itu semua dibangun keilmuan nahwu. Seiring perjalanan waktu disadari bahwa Ushul an-nahwi adalah proses pembentukan sejumlah kaidah nahwu yang bersumber dari keindahan bahasa dan harmonisasi ungkapan-ungkapan orang Arab."7

Dari beberapa pengertian di atas, dapat dipahami bahwaUshul an-nahwi tidak saja dipahami sebagai sejumlah kumpulan kaidah nahwu dalam berbagai persoalannya, tetapi dari termUshul an-nahwi juga dapat dipahami bagaimana sesungguhnya proses dalam pembentukan kaidah-kaidah nahwu tersebut. Dan ushul al-nahwi merupakan dasar pijakan dan sandaran dalam merumuskan kaidahkaidah tata bahasa Arab (ilmu nahwu) serta ilmu yang mengkaji tentang dalil-dalil nahwu (sintaksis Arab) secara global, baik dari aspek dalil itu sendiri maupun metode pengambilannya. Dan ia menyerupai undang-undang yang menjadi rujukan ketika para linguis Arab menghadapi perbedaan pendapat seputar permasalahan nahwu.

\footnotetext{
5 Ibnu Al-Anbari, Al-Iqrab fi Jadal wa Luma' al-Adillah fi Usul an-Nahwi.(Damaskus: Mathba'ah al-Jami'ah as-Suriah, 1957), hal. 80

${ }^{6}$ Jalâluddin As-Suyuti, Al-Iqtirah fi Ushûl an-Nahwi wa Jadalih, (Damaskus: Dâr al-Qalam, 1989), hal. 21

${ }^{7}$ Yasmadi, Kontribusi Pemikiran Ibnu Jinni Dalam Perkembangan Ilmu Nahu Abad Ke-4 H, (Padang: Imam Bonjol Press, 2013), hal. 76
} 


\section{PerkembanganUshulNahwi}

Sejarah pertumbuhan dan perkembangan nahwu danUshul an-nahwi sulit untuk dipisahkan, juga sulit untuk mengatakan mana yang dulu muncul apakah nahwu atauUshul an-nahwi. Secara sederhana mungkin dapat dikatakan bahwanahwu dalam pengertian kaidah-kaidahnya yang bersifat normatif adalah produk dariUshul an-nahwi, sehingga proses kelahiran nahwu bersamaan dengan proses terbentuknyaUshul an-nahwi.

Sebagaimana dijelaskan sebelumnya, bahwaUshul an-nahwi tidak saja dipahami sejumlah kumpulan kaidah nahwu dalam berbagai persoalannya, tetapi dari termUshul an-nahwi juga dapat dipahami bagaimana sesungguhnya proses dalam pembentukan kaidah-kaidah nahwu tersebut. Oleh sebab itu meskipun kemunculan ilmuUshul an-nahwi lebih belakangan dibanding ilmu nahwu itu sendiri, namun dalam pengaplikasiannyaUshul an-nahwi lebih dulu dibandingkan nahwu.

Proses formulasi atau pengkaidahan nahwu dilakukan para ahlinya seiring dengan perkembangan dan tuntutan metodologi sebuah ilmu. Jika konstruksi nahwu relatif sudah matang dan mapan pada masa al-Khalil ibnu Ahmad (100-175 H) dan Sibawaih (W.180 H) pada abad kedua hijriyah,Ushul an-nahwi baru mulai diformulasikan oleh Ibnu al-Sarraj (w. $316 \mathrm{H}$ ) pada abad ketiga hijriyah. ${ }^{8}$

Ahmad Toha Hasanin dalam pengantar bukunya yang berjudul alMukhtashar fi Ushul an-nahwimengemukakan bahwa secara periodik dalam bentuk karya tertulis ditemukan bahwa Ibnu Jinni (W.392 H) adalah orang yang pertama yang melontarkan konsepUshul an-nahwidalam kitabnya "الخصائص",

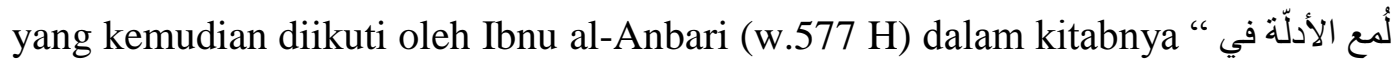
الاقتراح في أصول النحو “" dan as-Suyuti (w.911 H) dalam kitabnya

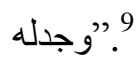

Akan tetapi pernyataan tersebut agaknya tidak dapat diterima oleh Asyraf Mahir Muhmud an-Nawaji. Ia bependapat bahwa istilahUshul an-nahwi pertama kali muncul abad ke-4 hijrah dikemukakan oleh Ibnu as-Sarraj, kemudian baru

${ }^{8}$ Muhbib Abdul Wahab, Pemikiran Linguistic Tammam Hassan Dalam Pembelajaran Bahasa Arab, (Jakarta: Uin Press, 2009), hal. 135

9 Ahmad Toha Hasanin, Al-Mukhtashar fi Usul an-Nahwi, (Kairo: Dâr Al-Busyra, 2005), hal. 1-2 
dipopulerkan oleh Ibnu Jinni, dan selanjutnya terhenti beberapa abad dan baru pada abad ke-6 dimunculkan lagi oleh al-Anbari. ${ }^{10}$

Dari keterangan tersebut dapat dipahami bahwa penggunaan istilah ushulan-nahwi pertama kali dikemukakan oleh ibnu as-Sarraj dalam kitabnya alushulfinnahwi, namun ibnu as-Sarraj belum mengkaji ushul an-nahwi tersebut secara terperinci, kemudian ibnu Jinny lah yang mengkaji ushul an-nahwi tersebut secara terperinci dalam kitabnya al-khashais yang kemudian diikuti oleh ibnu alAnbary dan as-Suyuti yang menyebarluaskan ushul nahwi sebagai sebuah ilmu yang matang.

\section{Al-Adillah an-Nahwiyah}

Perumusan kaidah-kaidah yang telah dilakukan oleh para ulama semenjak abad pertama hijriah sampai melewati beberapa fase pada dasarnya secara kualitas dan esensi materi telah berbicara tentang substansi Ushul an-nahwi. Sebab para ulama nahwu dalam merumuskan kaidah-kaidah nahwu mesti mendasarkan pada al-adillah an-nahwiyah yaitu sama', qiyâs, ijmâ' dan istishâb. Keempat sumber tersebut dijadikan oleh para ulama nahu sebagai dasar pembentukan kaidahkaidah nahu.

Ushul an-nahwimerupakan ilmu yang membahas tentang adillah annahwiyah secara menyeluruh, baik dari sisi dalil-dalilnya, metode istinbat dalam dalil tersebut serta aplikasi dengan al-adillah an-nahwiyah tersebut.

Dalam kitabnya, Ibnu Jinni menyatakan bahwa paling tidak ada tiga adillah an-nahwi yang utama yaitusama', qiyâs, dan ijmâ'. Tetapi setelah diteliti lebih jauh, pada prinsipnya Ibnu Jinni juga mengakui istishâb sebagai salah satu unsur dalamUshul an-nahwi.

Selanjutnya bagi al-Anbaridalam kitabnya Al-Ighrâb fi Jadal al-I'râb, dia menyatakan bahwa adillah an-nahwi paling tidak ada tiga, yaitu: naql, qiyâs, dan istishâb al-hâl. Namun dalam kitabnya yang lain (Luma'u al-Adillah fi 'Ilmi Ushul an-Nahwi) dia menambahkan ijmâ' sebagai dalil yang ke empat. Adapun

\footnotetext{
${ }^{10}$ Asyraf Mahir Mahmud An-Nawaji, Musthalahat 'Ilmu Usul Al-Nahw Dirasat Wa Kasyaf
} Ma ’jamiy, (Kairo: Dâr Gharib, 2001), hal. 9 
menurut as-Suyuti,adillah an-nahwiyah ada empat, yaitusama', ijmâ', qiyâs, danistishâb. ${ }^{11}$

Dari paparan beberapa pendapat di atas, pada umumnya yang menjadi objek dan perumusan kaidahUshul an-nahwi(al-adillah an-nahwiyah) adalah:

\section{a. Sama'}

Dalam peristilahan bahasa dan sastra Arab, sama' diatikan dengan bahasa yang didengar dari orang Arab yang benar-benar diyakini kefashihannya dalam berbahasa Arab, baik berbentuk lafaz maupun perkataan. ${ }^{12}$

Menurut as-Suyuti, sama'adalah sesuatu yang ditemukan dalam perkataan orang yang benar-benar diyakini kefashihannya, termasuk di dalamnya kalâmullah yaitu al-Qur'an, perkataan Nabi saw, dan perkataan orang Arab sebelum, pada masa dan sesudah periode rasul. ${ }^{13}$ Sedangkan menurut al-Anbari, sama' atau an-naql(istilah yang digunakan al-Anbari) adalah perkataan orang Arab yang fasih yang diperoleh dengan penukilan yang shahih dan sampai batas minimal atau mencapai batas mutawatir. ${ }^{14}$

Dari pengertian di atas dapat dipahami bahwa Al-naql atau sama' adalah ungkapan bahasa Arab yang fasih dan diterima melalui prosedur tertentu sehingga dapat dibedakan dan dijelaskan antara periwayatan yang jumlah perawinya sedikit dan yang banyak dan diyakini kefashihannya. Dari beberapa definisi ini dipahami bahwa al-naql bukan hanya merupakan metode, melainkan juga sebagai sumber dalil dalam membangun kaidah-kaidah nahwu. Sumber dalil ini ada tiga macam, yaitu al-Qur`an, hadis, dan kalam al-Arab (syair atau prosa).

Diantara contoh Sama' adalah:

1) Al-Qur'an

Ulama Basrah dan Kuffah tidak berbeda pendapat tentang kehujjahan teks al-Qur'an sebagai dalil nahu, karena al-Qur'an adalah kalam arab yang paling fasih dan terjauh dari perubahan dan penukaran. Tapi mereka berbeda dalam menetapkan qira'at

\footnotetext{
${ }^{11}$ Jâmi'ah al-Madinah al-‘Alâmiyah, Ushûl an-Nahwi I, (Madinah: Jâmi'ah al-Madinah al'Alâmiyah, tth.), hal. 155

${ }^{12}$ Emil Badi’ Yaqub, Qamus Al-Musthalahah Al-Lughawiyah Wa Al-Adabiyah, (Beirut: Dâr Al-'Ilm Li Al-Malayin, 1987), hal. 229

${ }^{13}$ As-Suyuti, al-iqtirah, op.cit., hal 36

14 Mahmud Ahmad Nahlah, Usul an-Nahwi Al'arabiy, (Beirut: Dâr al-Ma'rifah AlJami'iyah, 2002), hal. 31
} 
al-Qur'an yang dapat dijadikan sebagai dalil nahwu. Dimana ulama Basrah mereka lebih selektif dan ketat dalam menentukan qira'at yang dapat dijadikan sebagai dalil nahwu, bahkan mereka hanya menerima qira'at yang mutawatir (qira'ah sab'ah). Berbeda dengan ulama Kuffah, mereka tidak terlalu ketat dalam masalah qira'at.

Contoh:

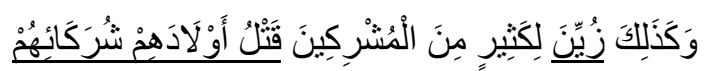

Riwayatkedua:

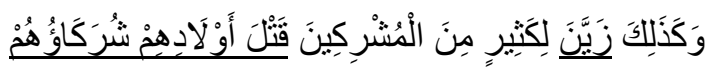

Dalam contoh di atas yang menjadi stressing adalah

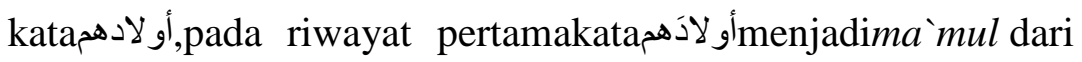
kata iقل

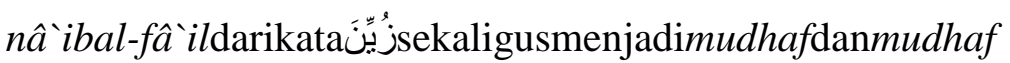

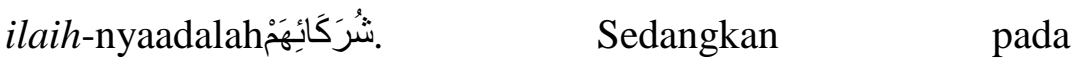

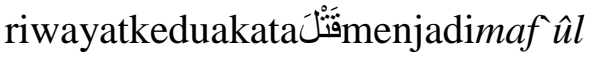
darikataَjَيَّekaligusmenjadimudhâf, dan mudhâfilaih-nya

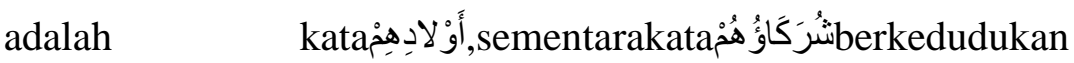
sebagai fầil dari زَيَّنَ.

2) Hadis Nabi

Ada perbedaan di kalangan para ahli bahasa untuk menyandarkan argumentasinya tentang kaidah sintaksis bahasa Arab terhadap hadis Nabi SAW. Perbedaan itu disebabkan, pertama, karena diperbolehkan meriwayatkan hadis Nabi hanya maknanya saja. Kedua, kesalahan ucap (allahn) sering terjadi dalam periwayatan hadis, karena sebagian besar perawinya adalah orang-orang non-Arab.

Oleh karena itu, dalam hal penggunaan hadis nabi sebagai dalil nahwu ulama basrah dan kuffah sangat sedikit menggunakannya, dan hanya menggunakan hadis-hadis yang riwayah bil lafzi saja. 
3) Kalamul 'Arab

Yang dimaksud dengan kalamul 'Arab disini ialah perkataan mereka yang berasal dari arab dan memiliki kefashihan dalam berbicara dan ucapannya terhindar dari penyimpangan bahasa. Kalam Arab tersebut baik berupa sya'ir maupun natsar.

Contoh:

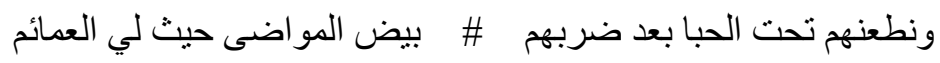

b. Qiyâs

Sebelum tumbuh dan berkembangnya qiyâs dalam ilmu nahwu, qiyâs terlebih dahulu muncul dalam bidang ilmu syari'ah dan ushul fiqh. Menurut ulama ushul fiqh, qiyâs adalah mengaitkan suatu perkara yang tidak ada nass-nya dengan perkara lain yang ada nass-nya karena antara kedua perkara tersebut ada kesamaan dalam 'ilat hukumnya. ${ }^{15}$ Dan secara terminologi tidak ada perbedaan yang mencolok antara qiyâs dalam ilmu nahwu dengan qiyâs dalam ilmu ushul fiqh. Yang membedakan hanya objek kajian dan 'ilat, dalam nahwu tentu yang dibahas adalah mengenai I'râb bahasa.

Dalam pandangan al-Anbary,qiyâs bukan hanya sebagai dalil nahwu melainkan lebih jauh daripada itu. Menurutnya seluruh nahwu adalah qiyâs, barangsiapa yang mengingkari qiyâs maka sesungguhnya ia mengingkari nahwu itu sendiri. ${ }^{16}$

Qiyas mempunyai fungsi penting dalam penelitian nahwu dan aktivitas kebahasaan pada umumnya. Menurut Ibrahim Anis, qiyas dipandang sebagai salah satu metode pengembangan bahasa, karena qiyas tidak lain adalah penyimpulan yang tidak diketahui sebelumnya (majhul) dari yang sudah diketahui (ma'lum). Dengan kata lain, qiyas kebahasaan adalah membandingkan kata-kata dengan kata lain, bentuk kata dengan bentuk

\footnotetext{
${ }^{15}$ Abdul Wahhab Khallaf, Ilmu Ushul al-Fiqh, (Indonesia: Al-Haramain, 2004), hal. 52

${ }^{16}$ Yasmadi, op cit., hal. 90
} 
lain, penggunaan kata atau kalimat dengan penggunaan lain dengan maksud melakukan ekstensifikasi kebahasaan. ${ }^{17}$

Metode qiyas dalam ilmu nahwu sama dengan metodeqiyas dalam ushul fiqh, ia mempunyai empat syarat yaitu hukum asal (al-ashl), hukum cabang (al-far`u), hukum dan illah.

Misalnya, menentukan hukum na ib al-fa il yang diqiyaskan terhadap fa il;

1. Al-ashl, setiap fa il dibaca rafa`.

2. Al-far`u, na`ib al-fail dibaca rafa`.

3. al-hukm, na`ib al-fail harus dibaca rafa`.

4. Illah, karena keduanya sama-sama sebagai musnad ileh.

c. Ijmâ'

Ijmâ' secara etimologi berarti kesepakatan atau consensus. Secara terminologiijmâ' dalam konteksUshul an-nahwi adalah kesepakatan yang terjadi pada ulama-ulama nahwu didua kota yaitu Basrah dan Kuffah, selama tidak bertentangan dengan ketetapan nas, teks dan qiyâs. ${ }^{18}$

Yang dimaksud dengan ijmầ di sini adalah kesepakatan ahli nahwubaik dari kalangan ulama Bashrah saja atau ulama Kufah saja atau kesepakatan kedua kota tersebut dalam membuat kaidah-kaidah nahwu. Keberadaan ijma` sebagai salah satu metode dalam melahirkan kaidahkaidah nahwu tidak berbeda dengan ijma`yang digagas oleh para fuqaha` untuk melahirkan keputusan hukum.

"لولاي و لولاك" " Misalnya, dalam potongan syair terdapat kalimat sebagian besar ahli nahwu Bashrah mengatakan bahwa dhamir ya` dan kaf menempati posisi jar. Berbeda dengan ahli nahwu Kufah, mereka berpendapat bahwa dhamir ya` dan kaf menempati posisi rafa` sebagai mubtada:

Ulama Basrah dan Kuffah sepakat bahwa khabar al mubtada' yang mensifati maka mengandungdhamir. Misal kalimat "عمر حسن، زيد قائم", lafadz فن disinimerupakankhabaral-

\footnotetext{
${ }^{17}$ Muhbib Abdul Wahab, op.cit, hal.146

${ }^{18}$ As-Suyuti, op.cit, hal. 66
} 
mubtada 'menyifatimubtada', dankeduanya

mengandung dhamir yang

kembali pada masing-masing yang disifati.

d. Istishâbul hâl

Secara sederhana para ulama fiqhmemaknai istishâb dengan tetapnya suatu hukum selama belum ada dalil yang merobahnya. Selanjutnya dalam perkembangan nahwu, istilah istishâb kemudian juga dikenal dan dijadikan sebagai al-adillah an-nahwiyah oleh sebagian ulama nahwu. Ada yang memandang bahwa istishâb bukan bagian dari dalil nahwu, sebaliknya juga ada yang memasukkannya sebagai dalil nahwu, misalnya al-Anbary. Bagi al-Anbari istishâb adalah bagian dari al-adillah annahwiyah yang diyakininya, tetapi ia sendiri mengungkapkan dasar hukum istishâb itu sendiri lemah. Istishâb tidak dapat digunakan sebagai dalil nahwu selama masih ditemukan dalil lain yang lebih kuat. ${ }^{19}$

Ishtishab adalah metode dalam menetapkan keadaan lafadz sesuai dengan hukum asalnya selama tidak ada dalil yang merubahnya. Misalnya, hukum asal isim adalah mu`rab selama tidak ditemukan dalil yang menunjukkan ke-mabni-annya, juga dengan fi ìl, hukum asalnya adalah mabni, selama tidak ditemukan dalil yang menunjukkan ke-mu`rab-annya.

Kaidahnya berbunyi:

$$
\text { الأصل فى الأسماء معرب حتى يوجد دليل البناء }
$$

"Pada dasarnya hukum isim adalah mu'rab, kecuali ditemukan satu dalil yang menunjukkan kemabniannya”.

$$
\text { الأصل فى الأفعال مبني حتى يوجد دليل الاعر اب }
$$

"Pada dasarnya hukum fi il adalah mabni, kecuali ditemukan satu dalil yang menunjukkan kemu`rabannya”.

\section{PengaruhUshul al-Fiqh terhadapUshulal-Nahwi}

Meskipun ushul fiqh dan Ushul an-nahwi merupakan dua wilayah keilmuan yang berbeda dan berdiri sendiri, tetapi antara keduanya memiliki hubungan yang sangat erat. Keberadaan kedua disiplin keilmuan sebagai

${ }^{19}$ Yasmadi, op cit., hal. 94 
prinsip dasar teoritis dan keeratan hubungan keduanya mengharuskan kita untuk melihat ilmu ushul fiqh dan Ushul an-nahwi dalam satu kerangka kajian.

IstilahUshul an-nahwi dalam banyak hal muncul dikalangan ulama nahwu dan terinspirasi oleh wacana keilmuan yang dikembangkan oleh ulama fiqh atauUshulfiqh.Ibnu Jinni pada bagian awal bukunya al-Khashâis, salah satu buku yang banyak membicarakanUshul an-nahwi, telah menjelaskan hal tersebut. Menurutnya, pengaruh ushul fiqhterhadapUshul an-nahwi sangat jelas terlihat. Paling tidak terlihat dari hubungan antara 'ilat nahwu dan 'ilat fiqh. Menurut Ibnu Jinni tidak seorangpun ulama Basrah dan Kuffah yang berlawanan dengan apa yang berkembang dikalangan ushul fiqh. ${ }^{20}$

Asyraf Mahir Mahmud an-Nawaji, juga mengemukakan bahwa dalam peristilahan qiyâs saja jelas terlihat pengaruh ushul fiqhterhadapUshul annahwi, misalnya istilah-istilah: al-'illah al-muta'addiyah, al-'illah almu'assirah, al-'illah ghair al-muta'addiyah, al-'illah ghair mu'assirah, al'illah al qasirah, al- 'illah al-waqifah ghair al-jariyah, al- 'illah al-muwajjahah, dan al- 'illah al-muwajjabah. ${ }^{21}$

Selain itu, dalam kajian ushul fiqhada 4 sumber hukum yang disepakati

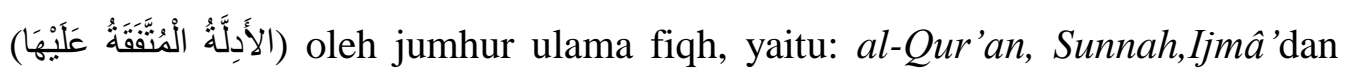
qiyâs. Dalam kajianUshul an-nahwi, para ulama nahwu baik yang masuk pada kelompok Basrah, Kuffah maupun Baghdad juga mengenal dan menyepakati keempat sumber hukum tersebut. Hanya saja muncul dengan istilah yang lain dan ditambah dengan orientasi pengembangannya. ${ }^{22}$ Ini adalah gambaran yang faktual bahwa pada awal kemunculannya ilmuUshul an-nahwi memang banyak berpengaruh oleh peristilahan-peristilahan dan substansi ilmu ushul fiqh.

Mahmud Ahmad Nahlah mengatakan bahwa ilmu ushul fiqhadalah ilmu yang paling banyak memberikan pengaruh pada kajian nahwu dibanding ilmu-ilmu lainnya. Bukti pengaruh tersebut diantaranya: ${ }^{23}$

a. Membuka inspirasi dan kecermatan yang menyeluruh terhadap-nas-nas yang dijadikan sumber (an-nushus) yang kemudian sangat bermanfaat

${ }^{20}$ Abul Fath Utsman Ibnu Jinni, al-Khashâis, (Kairo: Dâr al-Kutub al-Misriyah, 1952), juz 2, hal. 29

${ }^{21}$ Asyraf Mahir Mahmud An-Nawaji, op.cit, hal. 67-68

${ }^{22}$ Mahmud Ahmad Nahlah, op.cit., hal. 14

${ }^{23}$ Ibid., hal. 15-17 
untuk mengkritisi teks tersebut baik dari segi sanad (sumber)maupun matannya yang kemudian dipakai sebagai isytisyhâd.

b. Dalam wacana ushul fiqhdikenal kaidah ushul fiqhdengan konsep لاضرر ولا (المصلحة) yang terformulasi dengan kalimat ضرار)sedangkan dalam wacanaUshul an-nahwidikenal dalam kaidahUshul an-nahwi dengan konsep al-faidah (الفائدة)yang kemudian diformulasi dalam konsep (لا خطأو لا لبس).

Menurut Tamam Hasan, kaidah Qawaid at-Tawjih tersebut fungsinya sangat siqnifikan dalam ilmu nahwu, diantaranya: ${ }^{24}$

a. Konsep al-ashlu (الأصل) dan al-far'u (الفرع)telah berkembang sejak periode awal perkembangan nahwuyang mereka ambil dari kalangan ushul fiqh. Konsep tersebut untuk pertama kali dikemukakan oleh Imam Abu Hanifah dan teman-temannya. Semula kalangan ulamaUshul an-nahwi mengikuti kajian fiqh,kemudian mereka mengadopsi peristilahan-peristilahan tersebut sesuai kebutuhan dan keserasiannya. Misalnya al-Khalil bin Ahmad yang satu masa dengan imam Abu Hanifah, dan Sibawaih dengan Abu Yusuf.

b. Pengaruh al-'illah al-usuliyyah (العلة الأصولية) pada al-'illah annahwiyyah (العلة النحوية)sangat jelas terlihat dalam proses pembuatan dan pembenaran hukumnahwu dan untuk diterimanya hukumnahwu tersebut.

c. Kalangan nahwu terinspirasi juga dari kalangan ushul fiqhdalam hal tarjih, ketika menghadapi dua sama' atau lebih yang saling berlawanan atau dua qiyâs atau lebih yang saling berlawanan atau terdapatnya pertentangan anatara sama' dan qiyâs.

d. Kalangan nahwu banyak mentransfer peristilahan-peristilahan ushul fiqhkedalam nahwu, terutama yang berkaitan denganUshul an-nahwi dan cara menarik kesimpulan (thuruq al-astidlâl).

e. Terbaginya hukumnahwu kepada wajib (الوجوب),mamnû́(الامتناع), hasan(الحسن), qabîh (القبيح),khilâf al-ûla (مخالفة الأولى), jâiz 'ala as-sawâ'

${ }^{24}$ Tamam Hasan, Al-Usul;Dirasah Estimulujiah Li Al-Fikr Al-Lughawi 'Ind Al-'Arab, AnNahw, Fiqh Lughah, Al-Balaghah, (Kairo: Dar Al-Kutub, 1983), hal. 208-209 
(جائز على السواء), adalah sebagai indikator keterpengaruhan kalangannahwu oleh ulama-ulama ushul fiqh.

Dari penjelasan di atas sangat terlihat pengaruh besar ilmu ushul fiqh terhadap ushul nahwi, baik dari segi sumber menetapkan hukum maupun istilah-istilah yang digunakan dalam penetapan kaidah ushul nahwi. 


\section{Penutup}

Ushul an-nahwi adalah ilmu yang membahas atau mengkaji tentang aladillah an-nahwiyah (sumber hukum dalam nahwu), tata cara mengeluarkan kaidah-kaidah nahwu, serta pengaplikasiannya. Adapun yang dimaksud denganal-adillah an-nahwiyah adalahsama', qiyâs, ijmâ' ',dan istishâb.

KonsepUshul nahwi pertama kali muncul abad ke-4H dikemukakan oleh Ibn as-Sarraj, kemudian dipopulerkan oleh Ibn Jinni, kemudian pada abad ke-6 H kembali diikuti oleh al-Anbari dan as-Suyuti.

IstilahUshul an-nahwi dalam banyak hal muncul dikalangan ulama nahwu terinspirasi oleh wacana keilmuan yang dikembangkan oleh ulama fiqhatauUshulfiqh. IlmuUshulfiqhmerupakan ilmu yang paling banyak memberikkan pengaruh terhadap kajianUshul an-nahwi, hal ini dapat terlihat dari banyaknya istilah-istilah yang digunakan dalam ilmu Ushul an-nahwi yang diambil dari istilah-istlilah ushul fiqh. 


\section{Pustaka Acuan}

Abdul Wahab, Muhbib, Pemikiran Linguistic Tammam Hassan Dalam Pembelajaran Bahasa Arab, Jakarta: Uin Press, 2009

Al-'Alâmiyah, Jâmi'ah al-Madinah, Ushul an-Nahwi I, Madinah: Jâmi'ah alMadinah al-'Alâmiyah, tth.

Ibnu Al-Anbari, Al-Iqrab fi Jadal wa Luma' al-Adillah fi Usul an-Nahwi. Damaskus: Mathba'ah al-Jami'ah as-Suriah, 1957

Hasan, Tamam, Al-Usul;Dirasah Estimulujiah Li Al-Fikr Al-Lughawi 'Ind Al'Arab, An-Nahw, Fiqh Lughah, Al-Balaghah, Kairo: Dar Al-Kutub, 1983

Hasanin, Ahmad Toha, Al-Mukhtashar fi Usul an-Nahwi, Kairo: Dâr Al-Busyra, 2005

Ibnu Jinni, Abul Fath Utsman, al-Khashâis, Kairo: Dâr al-Kutub al-Misriyah, 1952

Khallaf, Abdul Wahhab, Ilmu Ushul al-Fiqh, Indonesia: Al-Haramain, 2004

Ibnu Manzhur, Muhammad bin Mukrim, Lisân al-'Arabi, Beirut: Dâr al-Shadir, 1414

Nahlah, Mahmud Ahmad, Usul an-Nahwi Al'arabiy, Beirut: Dâr al-Ma'rifah AlJami'iyah, 2002

An-Nawaji, Asyraf Mahir Mahmud, Musthalahat 'Ilmu Usul Al-Nahw Dirasat Wa Kasyaf Ma'jamiy, Kairo: Dâr Gharib, 2001

As-Shaban, Muhammad bin Ali, Hâsyiyah as-Shaban 'ala al-Asyumi, Beirut: Dâr al-Kutub al-'Ilmiyah, 1997

As-Suyuti, Jalâluddin, Al-Iqtirah fi Ushul an-Nahwi wa Jadalih, Damaskus: Dâr al-Qalam, 1989

Syallal, 'Arraq Jabr, al-'Alâqah baina 'ilmi Ushul al-Fiqh wa 'ilmi Ushul anNahwi, Tarmiyah: Al-Jâmi'ah al-'Irâqy, tth.

Yasmadi, Kontribusi Pemikiran Ibnu Jinni Dalam Perkembangan Ilmu Nahu Abad Ke-4 H, Padang: Imam Bonjol Press, 2013

Ya'qub, Emil Badi', Qamus Al-Musthalahah Al-Lughawiyah Wa Al-Adabiyah, Beirut: Dâr Al-'Ilm Li Al-Malayin, 1987 